\title{
KORELACE VELKOMORAVSKÝCH MALT, NEDOPALU A VÁPENCŮ Z LOKALITY BŘECLAV-POHANSKO S VÁPENCI VYTIPOVANÉ PROVENIENCE
}

\author{
Correlation of Great Moravian mortars, underburned limestones and limestones from the \\ Břeclav-Pohansko site with limestones of various provenance
}

\author{
Miroslava Gregerová, Dalibor Všianský, Ludmila Kurdíková \\ Ústav geologických věd PřF MU, Kotlářská 2, 61137 Brno; e-mail: mirka@sci.muni.cz
}

(34-23 Břeclav)

Key words: limestones, historical mortars, chemical composition

\begin{abstract}
The paper gives an overview of identification possibilities of limestones source used for lime burning in the Břeclav-Pohansko archaeological site based on their chemical composition and comparison with mortars. Limestones from three sites were examined: Skalica, Holíc, Hlohovec and Pálava hill. The chemical compositions of limestones were compared with composition of mortars and thermally undecomposed limestones from mortars. Hlohovec was excluded as a source site based on the results.
\end{abstract}

\section{Úvod}

Vápenné malty svými strukturními znaky a barvou odpovídají hrubě zrnitým pískovcům až jemně zrnitým slepencům s karbonátovým tmelem. Aplikace petrografických metod v oblasti maltovin dovoluje získat základní informace o skladbě plniva a pojiva. Mikropetrografické studium je často nenahraditelným zdrojem pro určení minerální a horninové povahy a velikosti částic plniva, charakteristiku jejich tvaru a posouzení mikrostruktury.

Název plnivo je používán pro označení klastických složek malt, které velikostí nejčastěji odpovídají pískové až drobné štěrkové frakci. Historické vápenné malty obsahují klasty výpalem nerozložených nebo jen částečně rozložených vápenců (tzv. vápenný nedopal). Pojivo historických malt je mikrokrystalické př́p. jemně krystalické. Původní kryptokrystalický charakter pojiva (tzv. hašeného vápna) je „smazán“ následnou rekrystalizací za vzniku mikritového karbonátu. Hašené vápno stmeluje zrna plniva a reakcí se vzdušným $\mathrm{CO}_{2}$ se zpevňuje a vzniká karbonátový tmel. Ve většině českých a moravských historických malt převažuje $\mathrm{v}$ pojivu kalcit, méně často lze identifikovat aragonit a vaterit. Součástí pojiva bývají příměsi jemných prachových a jílových částic.

Přehled o historických omítkách, technologických postupech jejich př́pravy, identifikaci vápenných pojiv, vlivu a charakteru používaných př́sad uvádí Hošek - Muk (1990), Kotlík (1999) a Hošek - Losos (2007). Používané materiály, technologii př́pravy vzdušných malt a jejich aplikace na historických omítkách sledovala Rovnaníková (2003, 2004). Historii výroby vápna a jeho vlastnosti popsala Rovnaníková (2009).

Petrografickou a geochemickou charakteristiku malt a omítek kostela sv. Petra a Pavla v Brně podali Gregerová - Vlček (1994). Petrografické rozbory malt, mikropetrografické analýzy a možnost relativního datování podle stupně degradace pojiva uveřejnili Gregerová (2000), Prix - Zezula (2000), Gregerová - Pospíšil (2001), Gregerová - Hložek (2003) a Gregerová et al. (2010).

Orientační chemické studium malt $\mathrm{v}$ rámci prováděného geofyzikálního výzkumu románské rotundy sv. Kateřiny ve Znojmě předložili Bílý et al. (1996) a Zeman - Růžičková (1996).

Studiem vlivu solí a mikroflóry na sanační omítky se zabývaly Gregerová - Zapletalová. (2003).

\begin{tabular}{|c|c|l|c|}
\hline Č. vz. & Druh & \multicolumn{1}{|c|}{ Lokalizace } & Původ \\
\hline $\mathbf{1}$ & malta & M2; obj. 34, žárové pohřebiště & Pohansko \\
\hline $\mathbf{2}$ & malta & M3; F046, SVP 2009, i. č. 242558 & Pohansko \\
\hline $\mathbf{3}$ & nedopal & B 64-35, PVR 23 & Pohansko \\
\hline $\mathbf{4}$ & nedopal & B 65-33, PVR 01 & Pohansko \\
\hline $\mathbf{5}$ & malta & M11; B 64-35, PVR 23; růžová & Pohansko \\
\hline $\mathbf{6}$ & malta & M10; A 9-57, i. č. P 9785/30; hlazená & Pohansko \\
\hline $\mathbf{7}$ & malta & M16; F 40, severní předhradí & Pohansko \\
\hline $\mathbf{8}$ & nedopal & F 40, severní předhradí & Pohansko \\
\hline $\mathbf{9}$ & malta & M17; kostel č. 1 sv. od schodů & Pohansko \\
\hline $\mathbf{1 0}$ & omítka & M22; kostel č. 1 omítka, přístavek čs. 605 & Pohansko \\
\hline $\mathbf{1 1}$ & nedopal & SVP 2009, hrob 72 & Pohansko \\
\hline $\mathbf{1 2}$ & nedopal & F 040, sch. B 64-35, SVP 2009, i. č. P 242496 & Pohansko \\
\hline $\mathbf{1 3}$ & vápenec & vápenec $\mathrm{z}$ výchozu & Holíč \\
\hline $\mathbf{1 4}$ & vápenec & vápenec $\mathrm{z}$ výchozu & Hlohovec \\
\hline $\mathbf{1 5}$ & vápenec & vápenec $\mathrm{z}$ výchozu & Skalica \\
\hline $\mathbf{1 6}$ & vápenec & vápenec $\mathrm{z}$ výchozu & Pálava \\
\hline
\end{tabular}

Tab. 1: Lokalizace a charakteristika analyzovaných vzorků fragmentů velkomoravských malt, nedopalu a vápenců $\mathrm{z}$ lokality Břeclav-Pohansko a vápenců vytipované provenience.

Tab. 1: Localization and characteristics of analyzed samples of Great Moravian mortars, underburned limestones and limestones from the Břeclav-Pohansko site and limestones of assumed provenance. 


\begin{tabular}{|c|c|c|c|c|c|c|c|c|}
\hline \multirow{2}{*}{\multicolumn{2}{|c|}{\begin{tabular}{|l|} 
Č. vzorku \\
Materiál
\end{tabular}}} & 1 & 2 & 5 & 6 & 7 & 9 & 10 \\
\hline & & malta & malta & malta & malta & malta & malta & omítka \\
\hline \multicolumn{2}{|c|}{ Lokalizace } & $\begin{array}{l}\text { M2; obj. 34, žá- } \\
\text { rové pohřebiště, }\end{array}$ & $\begin{array}{c}\text { M3; F046, } \\
\text { SVP 2009, i. č. } \\
242558\end{array}$ & $\begin{array}{l}\text { M11; B 64-35, } \\
\text { PVR 23; růžová }\end{array}$ & $\begin{array}{l}\text { M 10; A 9-57, } \\
\text { i. č. P 9785/30; } \\
\text { hlazená }\end{array}$ & $\begin{array}{l}\text { M16; F 40, se- } \\
\text { verní předhradí }\end{array}$ & $\begin{array}{l}\text { M17; kostel č. } 1 \\
\text { sv. od schodů }\end{array}$ & $\begin{array}{l}\text { M22; kostel č. } 1 \\
\text { omítka, přísta- } \\
\text { vek čs. } 605\end{array}$ \\
\hline \multicolumn{2}{|c|}{ Barva } & šedá & světle okrová & růžová & šedobílá hutná & šedá & $\begin{array}{c}\text { světle hnědá, } \\
\text { našedlá }\end{array}$ & $\begin{array}{l}\text { světle hnědá, } \\
\text { našedlá }\end{array}$ \\
\hline \multirow{5}{*}{\multicolumn{2}{|c|}{ Granulometrie }} & $>10 \mathrm{~mm}: 12 \%$ & $>10 \mathrm{~mm}: 9 \%$ & $>10 \mathrm{~mm}: 9 \%$ & $>10 \mathrm{~mm}: 2 \%$ & $>10 \mathrm{~mm}: 14 \%$ & $>10 \mathrm{~mm}: 7 \%$ & $>5 \mathrm{~mm}: 5 \%$ \\
\hline & & $>5 \mathrm{~mm}: 15 \%$ & $>5 \mathrm{~mm}: 12 \%$ & $>5 \mathrm{~mm}: 17 \%$ & $>5 \mathrm{~mm}: 3 \%$ & $>5 \mathrm{~mm}: 9 \%$ & $>5 \mathrm{~mm}: 3 \%$ & $<1 \mathrm{~mm}: 10 \%$ \\
\hline & & $<1 \mathrm{~mm}: 33 \%$ & $<1 \mathrm{~mm}: 42 \%$ & $<1 \mathrm{~mm}: 41 \%$ & $<1 \mathrm{~mm}: 48 \%$ & $<1 \mathrm{~mm}: 46 \%$ & $<1 \mathrm{~mm}: 52 \%$ & $<1 \mathrm{~mm}: 36 \%$ \\
\hline & & $<1 \mathrm{~mm}: 42 \%$ & $<1 \mathrm{~mm}: 35 \%$ & $<1 \mathrm{~mm}: 33 \%$ & $<1 \mathrm{~mm}: 33 \%$ & $<1 \mathrm{~mm}: 31 \%$ & $<1 \mathrm{~mm}: 38 \%$ & $<0,5 \mathrm{~mm}: 49 \%$ \\
\hline & & & & & $<0,5 \mathrm{~mm}: 14 \%$ & & & \\
\hline \multicolumn{2}{|c|}{ Mikrostruktura } & sparit & $\begin{array}{c}\text { mikrit, } \\
\text { rekrystalizační }\end{array}$ & $\begin{array}{c}\text { mikrit, } \\
\text { rekrystalizační }\end{array}$ & $\begin{array}{c}\text { mikrit, } \\
\text { rekrystalizační }\end{array}$ & $\begin{array}{c}\text { sparit, } \\
\text { rekrystalizační }\end{array}$ & $\begin{array}{c}\text { mikrit, } \\
\text { rekrystalizační }\end{array}$ & $\begin{array}{c}\text { mikrit, } \\
\text { rekrystalizační }\end{array}$ \\
\hline \multirow{2}{*}{\multicolumn{2}{|c|}{ Nedopal }} & bílé hrudky & bílé hrudky & bílé hrudky & $\begin{array}{l}\text { rozpraskané, } \\
\text { podél trhlin }\end{array}$ & $\begin{array}{c}\text { drobné bílé } \\
\text { hrudky }\end{array}$ & bílé hrudky & bílé hrudky \\
\hline & & $>1 \mathrm{~cm}$ & $>1 \mathrm{~cm}$ & $>1 \mathrm{~cm}$ & rekrystalizace & $<1 \mathrm{~cm}$ & $>1 \mathrm{~cm}$ & $>1 \mathrm{~cm}$ \\
\hline \multicolumn{2}{|c|}{ Pórovitost } & $16 \%$ & $15 \%$ & $17 \%$ & $14 \%$ & $17 \%$ & $17 \%$ & $16 \%$ \\
\hline \multicolumn{9}{|c|}{ Mikropetrografická analýza } \\
\hline \multirow{14}{*}{ 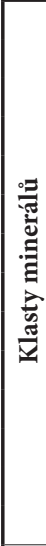 } & Křemen & ++ & ++ & ++ & + & ++ & + & + \\
\hline & Živce & + & + & + & + & + & + & + \\
\hline & Slídy & + & + & + & + & ++ & + & + \\
\hline & Amfibol & + & + & + & + & + & + & + \\
\hline & Pyroxen & & & & & & + & + \\
\hline & Epidot & + & & & + & & + & + \\
\hline & Kyanit & & & & & & + & + \\
\hline & Sillimanit & + & + & + & + & & & \\
\hline & Chlorit & + & & & & + & & \\
\hline & Glaukonit & & & & & + & & \\
\hline & Granát & & + & + & + & + & + & \\
\hline & Staurolit & & & + & + & & & \\
\hline & Kalcit & + & + & + & + & + & + & + \\
\hline & Zirkon & + & + & + & + & + & + & + \\
\hline \multirow{7}{*}{ 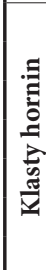 } & Křemence & + & + & + & + & + & + & + \\
\hline & Aplit & + & + & + & + & + & + & + \\
\hline & Ruly & & & & + & + & + & + \\
\hline & Svory, fylity, & + & & + & + & + & + & + \\
\hline & břidlice & & & & & & & \\
\hline & Mramory & & + & & + & + & + & ++ \\
\hline & \begin{tabular}{|l|} 
Pískovce \\
\end{tabular} & + & & + & & + & & \\
\hline
\end{tabular}

Poznámka: Ve věech studovaných maltách byly identifikovány úlomky keramiky.

Tab. 2: Strukturní a mikropetrografická charakteristika studovaných malt.

Tab. 2: Structural and micropetrographic characteristics of examined mortars.

\begin{tabular}{|c|c|c|c|c|c|c|c|c|c|c|c|c|c|c|c|c|c|}
\hline Č. vzorku & 1 & 2 & 5 & 6 & 7 & 9 & \multirow{3}{*}{\begin{tabular}{|c|}
10 \\
omítka \\
\end{tabular}} & 3 & 4 & 8 & 11 & 12 & 13 & 14 & 15 & 16 & 17 \\
\hline Materiál & & & & lty & & & & \multicolumn{5}{|c|}{ nedopal } & \multicolumn{5}{|c|}{ vápenec } \\
\hline Lok. & \multicolumn{6}{|c|}{ Pohansko } & & \multicolumn{5}{|c|}{ Pohansko } & Holič & Hlohovec & Skalica & Pálava & PAAS \\
\hline $\mathrm{SiO}_{2}$ & 60,3 & 36,2 & 26,0 & 39,6 & 31,4 & 62,6 & 52,9 & 27,7 & 6,6 & 2,5 & 4,6 & 1,0 & 37,8 & 3,6 & 12,9 & 8,0 & 62,4 \\
\hline $\mathrm{TiO}_{2}$ & 0,2 & 0,1 & 0,1 & 0,1 & 0,1 & 0,2 & 0,1 & 0,1 & 0,0 & 0,0 & 0,0 & 0,0 & 0,1 & 0,0 & 0,0 & 0,2 & 1,0 \\
\hline $\mathrm{Al}_{2} \mathrm{O}_{3}$ & 5,3 & 3,5 & 2,5 & 2,0 & 3,2 & 6,2 & 2,5 & 2,6 & 0,7 & 0,2 & 0,2 & 0,4 & 1,6 & 0,7 & 0,6 & 2,6 & 18,8 \\
\hline $\mathrm{Fe}_{2} \mathrm{O}_{3}$ & 0,9 & 0,6 & 0,5 & 0,4 & 0,6 & 1,3 & 0,4 & 0,5 & 0,1 & 0,1 & 0,0 & 0,2 & 0,2 & 0,5 & 0,5 & 1,7 & 7,2 \\
\hline $\mathrm{MgO}$ & 0,4 & 0,4 & 0,4 & 0,5 & 0,6 & 0,5 & 0,4 & 0,5 & 0,5 & 0,5 & 0,5 & 0,4 & 1,9 & 1,0 & 0,7 & 1,3 & 2,2 \\
\hline $\mathrm{CaO}$ & 15,9 & 31,3 & 38,9 & 31,3 & 34,6 & 14,2 & 23,1 & 37,5 & 51,2 & 54,3 & 53,4 & 54,5 & 31,2 & 51,9 & 47,5 & 47,1 & 1,3 \\
\hline $\mathrm{Na}_{2} \mathrm{O}$ & 1,0 & 0,7 & 0,5 & 0,3 & 0,6 & 1,1 & 0,4 & 0,5 & 0,2 & 0,1 & 0,0 & 0,0 & 0,2 & 0,1 & 0,1 & 0,2 & 1,2 \\
\hline $\mathrm{K}_{2} \mathrm{O}$ & 1,8 & 1,2 & 0,9 & 0,8 & 1,1 & 2,0 & 1,0 & 0,9 & 0,2 & 0,1 & 0,1 & 0,1 & 0,6 & 0,2 & 0,2 & 1,0 & 3,7 \\
\hline $\mathbf{P}_{2} \mathbf{O}_{5}$ & 0,1 & 0,2 & 0,1 & 0,1 & 0,1 & 0,1 & 0,1 & 0,0 & 0,0 & 0,0 & 0,0 & 0,1 & 0,1 & 0,1 & 0,1 & 0,1 & 0,2 \\
\hline MnO & 0,0 & 0,0 & 0,0 & 0,0 & 0,0 & 0,0 & 0,0 & 0,0 & 0,0 & 0,0 & 0,0 & 0,0 & 0,0 & 0,0 & 0,1 & 0,1 & 0,1 \\
\hline LOI & 14,0 & 25,7 & 30,0 & 25,0 & 27,7 & 11,8 & 19,0 & 29,6 & 40,3 & 42,3 & 41,1 & 43,2 & 26,3 & 41,7 & 37,4 & 37,6 & 35,0 \\
\hline Sum & 99,9 & 99,9 & 99,9 & 99,9 & 99,9 & 100,0 & 100,0 & 100,0 & 99,9 & 100,0 & 100,0 & 100,0 & 99,9 & 99,8 & 99,9 & 99,9 & 98,0 \\
\hline
\end{tabular}

Tab. 3: Zastoupení hlavních oxidů (hm. \%) ve fragmentech velkomoravských malt a nedopalu z lokality Břeclav-Pohansko a vápenců z vytipované provenience. Hodnoty standardu PAAS (Post-Archean Average Shale) jsou převzaty z Taylor - McLennan (1985).

Tab. 3: Analysis of main oxides (wt. \%) of fragments of Great Moravian mortars and underburned limestones from the Břeclav-Pohansko site and limestones of assumed provenance. The values of PAAS (Post-Archean Average Shale) standard come from Taylor - McLennan (1985). 


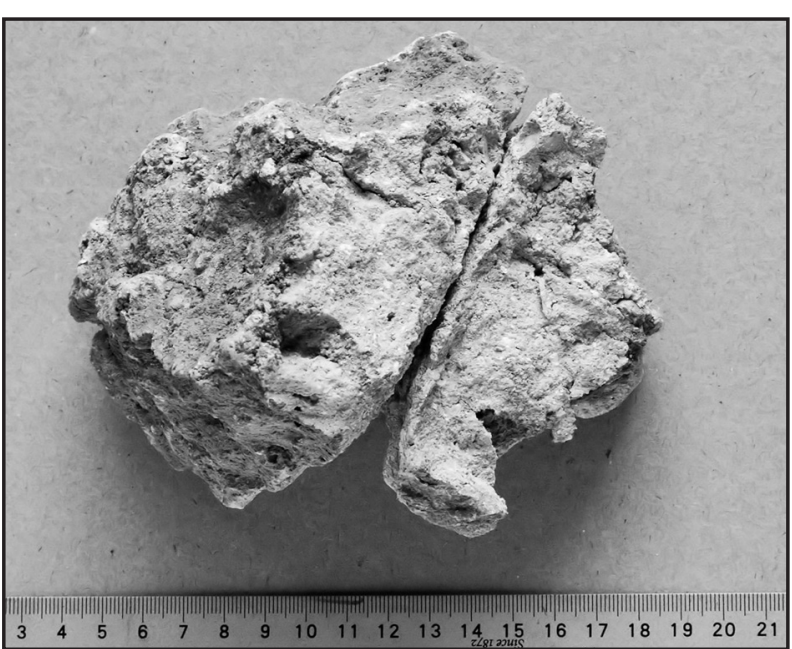

Obr. 1: Malta - objekt 34, žárové pohřebiště.

Fig. 1: Mortar from object 34, cremation burial ground.

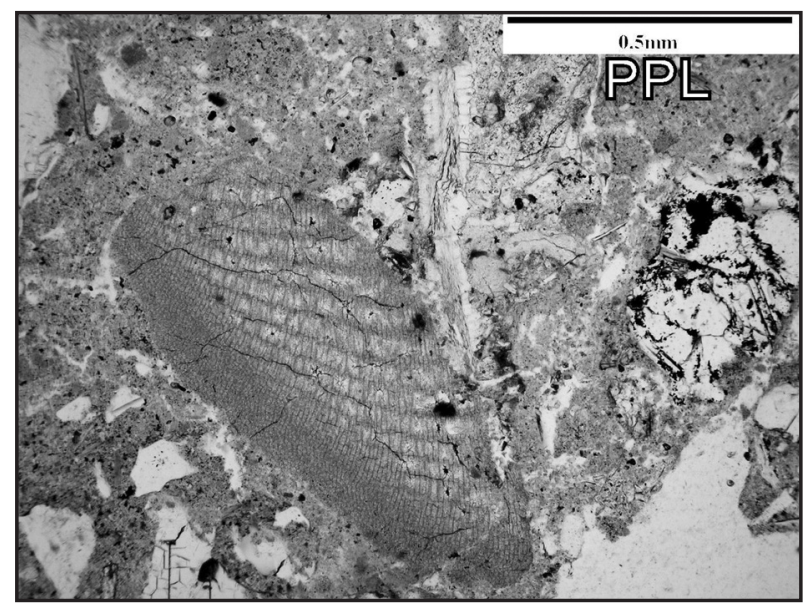

Obr. 3: Úlomek schránky měkkýše, malta; obj. 34, žárové pohřebiště (vz. 1).

Fig. 3: Fragment of mollusc shell, mortar from object 34, cremation burial ground (sample 1).

\section{Metody}

Při výzkumu malt preferujeme metody použivané v geologických vědách. Mikropetrografické rozbory a fotodokumentace byly provedeny pomocí petrografického mikroskopu Olympus BX-51. Mikropetrografické rozbory používáme $\mathrm{k}$ určení materiálového složení plniva a k upřesnění jeho zdroje (ř́ční písek, eluvium, klasty keramiky, strusky, skla, biomasa atd.). Spolu s tím lze stanovit poměr pojiva - plniva, identifikovat a určit obsah nedopalu. Analýzami částečně rozložených částic lze nezř́íka upřesnit charakter výchozího karbonátu (vápenec, biomikritový vápenec, mramor atd.), jeho mikrostrukturu a rekrystalizaci. Uvedená data poskytují požadované informace pro experimentální archeologii - napodobení technologického procesu.

S ohledem na omezený rozsah př́spěvku je předkládaná studie orientována na ověření možnosti identifikace zdroje vápencủ pro pálení vápna pomocí chemických analýz.

Chemické silikátové analýzy hlavních a stopových prvků byly provedeny v laboratoríích Acme (Vancouver,

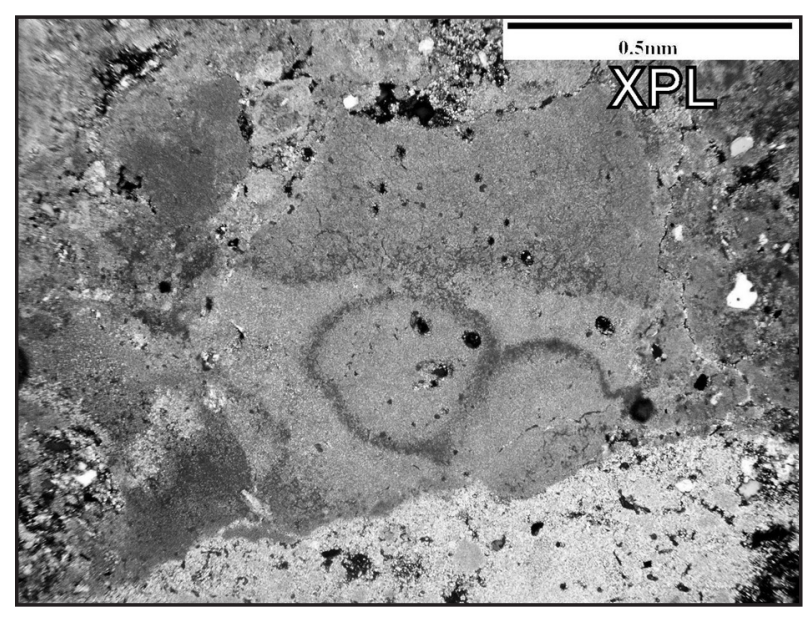

Obr. 2: Vápenný nedopal a rekrystalizace mikritu v růžové maltě (M11; B 64-35, PVR 23; vz. 5).

Fig. 2: Underburned limestone and micrite recrystallization in pinkish mortar (M11; B 64-35, PVR 23; sample 5).

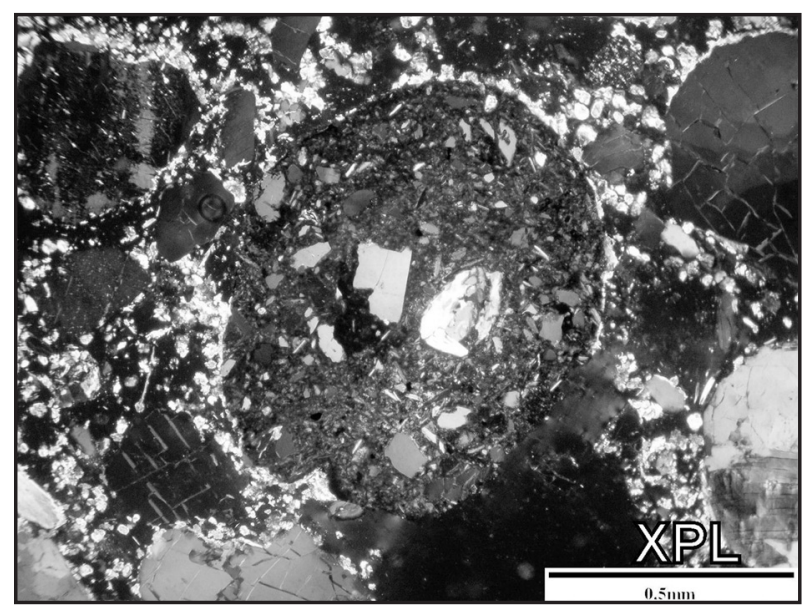

Obr. 4: Úlomek keramiky v maltě; obj. 34, žárové pohřebiště (vz. 1).

Fig. 4: Fragment of ceramics in mortar from object 34, cremation burial ground (sample 1).

Canada). Chemické analýzy byly vyhodnocovány pomocí programu Excel, obsahy normativních minerálů byly vypočteny pomocí programu MINLITH a statistické hodnoty, spider a ternární diagramy byly vyhodnoceny programem GCDkit 2.3. Detailní mikropetrografická, mikrostrukturní a geochemická klasifikace studie vápencových klastů (př́irodních nebo tzv. nedopalu) z plniva historických malt je určitým zdrojem informací o sociálně ekonomické struktuře společnosti a dovoluje vytipovat provenienci vápenců.

\section{Materiál}

Analyzovány byly raně středověké malty, vápenný nedopal a vápence použité jako stavební kameny z depozit archeologického výzkumu Břeclav-Pohansko. Pro porovnání byly analyzovány vápence $\mathrm{z}$ lokalit vytipovaných Šedivým (2010) a Přichystalem et al. (2008) z Holíče a Skalice a tyto byly doplněny vzorky vápence $z$ Hlohovce u Lednice a z historického lomu na kopci Pálava, Pavlovské vrchy. Celkem bylo pro potřeby chemických analýz použito 7 různých vzorků maltovin, 5 vzorků z malt separovaných nedopalů a 4 vápence (viz tab. 1). 


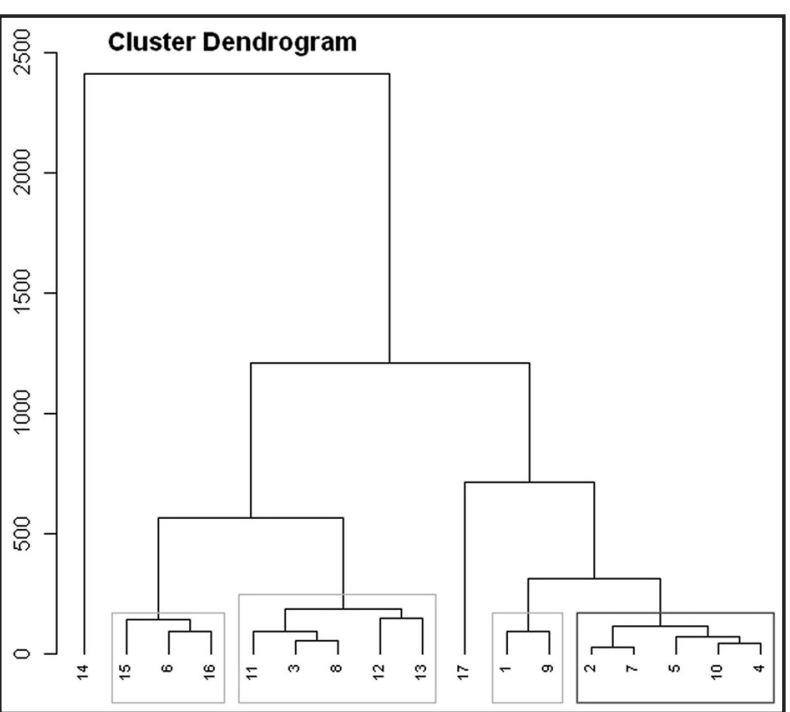

Obr. 5: Klastrová analýza fragmentů velkomoravských malt a nedopalu $\mathrm{z}$ lokality Břeclav-Pohansko a vápenců vytipované provenience.

Fig. 5: Cluster analysis of Great Moravian mortars' fragments, underburned limestone from the Břeclav-Pohansko site and limestones of assumed provenance.

\section{Výsledky}

\section{Mikropetrografická charakteristika}

Mikropetrografická analýza studovaných malt z Pohanska je přehledně shrnuta v tabulce 2 . Vápence, které byly používány pro pálení vápna, se pravděpodobně vyznačovaly proměnlivým obsahem oxihydroxidů Fe. Variabilita jejich obsahu, procentuální množství přídavku hašeného vápna $\mathrm{v}$ maltách, realizace expozice na stavebních objektech, různé klimatické podmínky a následná depozice $\mathrm{v}$ půdě, včetně ovlivnění ekosystému, se $\mathrm{v}$ konečném důsledku zohlednily $\mathrm{v}$ různých barevných tónech malt. V maltách se vyskytují relikty špatně vypálených vápenců,

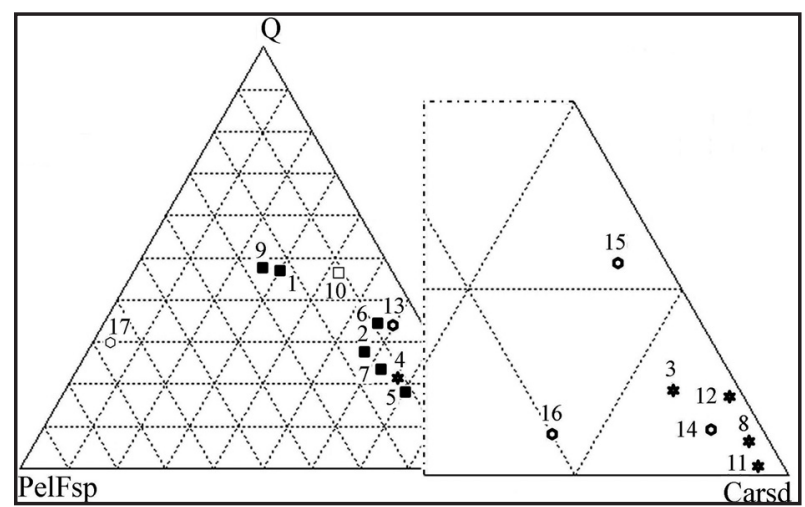

Obr. 6: Ternární diagram normativního složení PelFsp-Q-Cc studovaných malt, jejich nedopalu, studovaných vápenců (stavebních kamenů) z lokality Břeclav-Pohansko a vápenců vytipované provenience. ( $\mathrm{Q}$ - normativní křemen, PelFsp - suma živců a jílových minerálů, Carsd - suma uhličitanů).

Fig. 6: Ternary diagram of PelFsp-Q-Cc normative composition of examined mortars, underburned limestone from them and limestones (building stones) from the Břeclav-Pohansko site and limestones of assumed provenance. ( $\mathrm{Q}$ - normative quartz, PelFsp - sum of feldspars and clay minerals), Carsd - sum of carbonates).

které dokládají, že pro pálení vápna byly použity netříděné kusy vápenců. Vzácně byly identifikovány úlomky keramiky. Pro názornost jsou přiloženy obr. 1-4.

\section{Chemické analýzy}

Základní hypotézy o provenienci vápenců používaných pro výpal vápna do malt na velkomoravském Pohansku byly vyvozeny ze vzájemných korelací obsahů hlavních a stopových prvků (tab. 3).

Pro celkové posouzení podobnosti studovaných fragmentů velkomoravských malt a nedopalu a vápenců vytipované provenience byla využita shluková (klastrová) analýza. Použita byla Wardova metoda hledající vzdálenos-

\begin{tabular}{|c|c|c|c|c|c|c|c|c|c|c|c|c|c|c|c|c|c|}
\hline Č. vzorku & 1 & 2 & 5 & 6 & 7 & 9 & 10 & 3 & 4 & 8 & 11 & 12 & 13 & 14 & 15 & 16 & 17 \\
\hline Materiál & \multicolumn{6}{|c|}{ malta } & omít. & \multicolumn{5}{|c|}{ nedopal } & \multicolumn{4}{|c|}{ vápence } & PAAS \\
\hline LREE & 39,4 & 40,2 & 30,7 & 14,0 & 27,2 & 36,9 & 43,6 & 9,2 & 23,4 & 2,7 & 0,0 & 5,2 & 30,4 & 14,4 & 24,2 & 61,8 & 167,1 \\
\hline HREE & 5,4 & 3,8 & 3,2 & 2,9 & 4,4 & 5,4 & 2,6 & 1,1 & 3,4 & 0,6 & 0,3 & 0,9 & 5,3 & 2,2 & 3,5 & 8,3 & 17,6 \\
\hline REE & 44,8 & 43,9 & 33,9 & 16,8 & 31,6 & 42,3 & 46,2 & 10,3 & 26,8 & 3,3 & 0,3 & 6,1 & 35,7 & 16,6 & 27,7 & 70,1 & 184,7 \\
\hline $\mathrm{CaO}$ & 15,9 & 31,3 & 38,9 & 31,3 & 34,6 & 14,2 & 23,1 & 37,5 & 51,2 & 54,3 & 53,4 & 54,5 & 31,2 & 51,9 & 47,5 & 47,1 & 1,3 \\
\hline $\mathrm{La}_{\mathrm{n}} / \mathrm{Yb}_{\mathrm{n}}$ & 7,4 & 15,9 & 12,2 & 4,1 & 5,6 & 6,9 & 20,2 & 12,5 & 7,1 & 10,2 & 8,2 & 9,9 & 7,2 & 9,6 & 8,3 & 9,5 & 9,2 \\
\hline $\mathrm{La}_{\mathrm{n}} / \mathrm{Sm}_{\mathrm{n}}$ & 3,4 & 3,4 & 5,1 & 3,9 & 3,3 & 3,0 & 4,7 & 4,0 & 3,6 & 7,0 & 5,4 & 5,3 & 3,0 & 4,4 & 2,7 & 3,5 & 4,3 \\
\hline $\mathrm{La} / \mathrm{Sc}$ & 4,9 & 8,9 & 8,1 & 3,5 & 3,1 & 3,0 & 9,8 & 2,2 & 5,4 & 0,9 & 0,6 & 1,6 & 7,0 & 4,4 & 5,0 & 3,9 & 2,4 \\
\hline $\mathrm{La} / \mathrm{Co}$ & 3,6 & 4,9 & 3,5 & 7,0 & 4,1 & 2,5 & 12,3 & 11,0 & 3,4 & 4,5 & 3,0 & 8,0 & 11,7 & 1,3 & 5,6 & 2,1 & 1,7 \\
\hline Th/Sc & 3,7 & 3,2 & 2,2 & 1,1 & 2,3 & 2,8 & 6,8 & 0,5 & 1,9 & 0,3 & 0,2 & 0,2 & 1,7 & 0,6 & 1,1 & 2,4 & 0,9 \\
\hline Th/Co & 1,4 & 1,8 & 1,0 & 2,2 & 1,5 & 0,8 & 8,5 & 2,5 & 1,2 & 1,5 & 1,0 & 1,0 & 2,8 & 0,2 & 1,2 & 0,3 & 0,6 \\
\hline $\mathrm{Cr} / \mathrm{Th}$ & 10,8 & 6,3 & 22,7 & 18,2 & 17,4 & 10,7 & 2,9 & 40,0 & 10,5 & 66,7 & 100,0 & 100,0 & 23,5 & 116,7 & 27,3 & 8,3 & 7,5 \\
\hline $\mathrm{Th} / \mathrm{Cr}$ & 0,09 & 0,16 & 0,04 & 0,06 & 0,06 & 0,09 & 0,34 & 0,03 & 0,1 & 0,02 & 0,01 & 0,01 & 0,04 & 0,01 & 0,04 & 0,12 & 0,13 \\
\hline $\mathrm{V} /(\mathrm{V}+\mathrm{Ni})$ & 0,46 & 0,33 & 0,35 & 0,51 & 0,29 & 0,35 & 0,29 & 0,39 & 0,29 & 0,29 & 0,46 & 0,41 & 0,35 & 0,29 & 0,29 & 0,29 & 0,73 \\
\hline $\mathrm{Ce} / \mathrm{Ce}^{*}$ & 0,9 & 1,0 & 0,9 & 0,9 & 0,9 & 0,9 & 1,0 & 0,9 & 0,9 & 0,8 & 1,0 & 0,6 & 0,9 & 0,8 & 1,0 & 0,8 & 1,0 \\
\hline $\mathbf{E u} / \mathbf{E u}{ }^{*}$ & 0,8 & 0,6 & 0,9 & 0,8 & 0,8 & 0,8 & 0,5 & 0,7 & 0,8 & 0,6 & 0,7 & 1,3 & 0,7 & 0,7 & 0,7 & 0,7 & 0,7 \\
\hline $\mathrm{Eu} / \mathrm{Ce}$ & 0,2 & 0,2 & 0,2 & 0,2 & 0,3 & 0,3 & 0,1 & 0,2 & 0,3 & 0,2 & 0,2 & 0,5 & 0,3 & 0,3 & 0,3 & 0,3 & 0,1 \\
\hline $\mathrm{Th} / \mathrm{U}$ & 3,4 & 3,2 & 4,4 & 1,6 & 3,8 & 4,0 & 9,7 & 1,7 & 2,7 & 3,0 & 0,1 & 0,2 & 1,7 & 0,4 & 1,2 & 1,5 & 4,7 \\
\hline
\end{tabular}

Tab. 4: Rozsah poměrů vybraných prvků malt a vápenného nedopalu z fragmentů velkomoravských malt z lokality Břeclav-Pohansko a vápenců vytipované provenience. Pro srovnání jsou uvedeny hodnoty PAAS.

Tab. 4: Ratios of chosen elements of mortars and underburned limestones from the Břeclav-Pohansko site, limestones of assumed provenance, and PAAS values. 

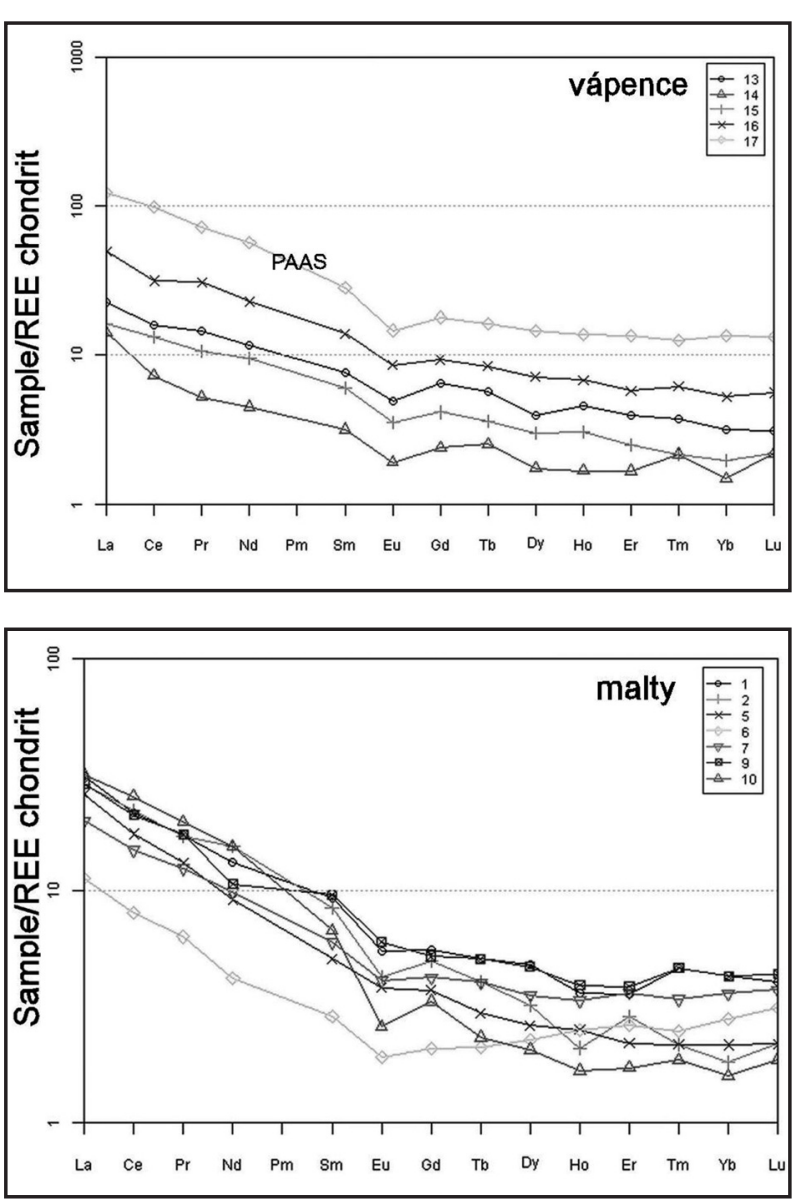

ti homogenní skupiny pomocí minimalizace sumy čtverců odchylek pro všechny možné dvojice subobjektů v každém kroku tvorby hierarchické struktury (obr. 5).

Výsledek provedené analýzy dovoluje předložit několik hypotéz:

- Pro pálení vápna nebyly používány vápence z Hlohovce (vz. 14).

- První skupinu s podobnými vlastnostmi tvoří nedopaly z malt ( vz. 3, 8, 11, 12) a vápenec z Holíče (vz. 13).

- V druhé je zastoupena malta vz. 6, má chemické složení blízké pálavskému vápenci (vz. 16) a vápenci ze Skalice (vz. 15).

- Do třetí skupiny se shlukují malty (vz. 2, 7, 5), omítka (vz. 10) a nedopal (vz. 4, separovaný z malty vz. 5).

- Čtvrtá zahrnuje malty vz. 1 (žárové pohřebiště) a vz. 9 (kostel 1, sv. od schodů).

\section{Normativní minerální složení plniva}

Velikost zrna termicky metamorfovaného a následnè rekrystalizovaného vzdušného vápenného pojiva v maltách nám obvykle nedovoluje identifikovat primární (popřípadě výpalem novotvořené) minerální fáze. Určitou představu o pravděpodobných minerálních fázích můžeme získat z poměrného zastoupení oxidů hlavních prvků. Znalost prvkového složení nám umožňuje vypočítat normativní molekuly minerálů a celkové normativně minerální složení malt a omítek.

Normativní minerální molekuly představují nejjednodušší chemické vzorce minerálů (Rosen et al. 2004).

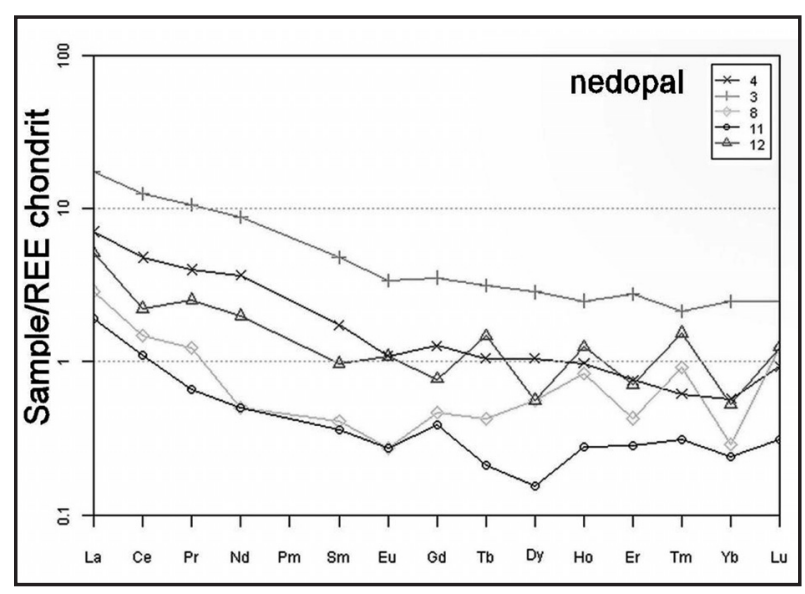

Obr. 7: Chondritem normalizovaný diagram vápenců, nedopalu a malt z Břeclavi-Pohanska.

Fig. 7: Diagram of limestones, underburned limestones from mortars from the Břeclav-Pohansko site normalized by chondrite.

Prvkové složení studovaných malt a nedopalu z lokality Břeclav-Pohansko a vápenců $\mathrm{z}$ vytipované provenience bylo přepočteno na základní normativní minerály.

Již na první pohled je parný logický rozdíl mezi normativním složením malt a vápenců. $\mathrm{V}$ maltách jsou výrazně vyšší podíly normativních živců, křemene. Analyzované vápence mají nízké podíly písčité a jílové frakce. Výsledky potvrzují předchozí formulace shlukové analýzy.

Projekcí normativních minerálů v ternárním diagramu PelFsp-Q-Cc (obr. 1) je zřejmé, že malty vz. 1 (obj. 34, žárové pohřebiště) a vz. 9 (kostel č. 1 sv. od schodů) mají nejvyšší obsahy normativního křemene, živců a jílových minerálů v plnivu. Vyšší obsah normativních živců a jílových minerálů má omítka vz. 10, obsahy karbonátů posouvají statisticky srovnatelné vzorky malt vz. 2, vz. 5 a vz. 7 stále více ve prospěch karbonátů. Do stejného pole se promítá i vápenný nedopal vz. 4 . Na rozdíl od klastrové analýzy se zde normativně zobrazí malta vz. 6 a vápenec z Holíče (vz. 13). Normativní složení analyzovaných nedopalů (vz. 3, 8, 12 a 11) a vápence $\mathrm{z}$ Hlohovce, z Pálavy, z Pohanska (vz. 14, 15, 16) se promítají do těsné blízkosti vrcholu normativních karbonátů (obr. 6). Pro názornost je doložena norma vypočtená pro PAAS (vz. 17).

\section{Stanovení stopových prvků}

Hlavním cílem studie bylo zjistit, zda chemické analýzy malt a vápenného pojiva mohou prokázat různou či shodnou provenienci vápence a současně identifikovat rozdíly mezi maltou a nedopalem.

S ohledem na stanovení primárního zdroje surovin byly LREE a HREE normalizovány chondritem (Boyton 1984). Chondritem normalizované křivky (obr. 7) malt, vápenců i nedopalu jsou obecně shodné a vykazují obohacení LREE. Obr. 7 dokládá, že i přes rozdíly v absolutním obohacení REE analyzovaných vzorků, existuje mezi analyzovanými vápenci, maltami a nedopalem nezanedbatelná podobnost.

V porovnání se standardem PAAS (Taylor - McLennan 1985) nejsou výsledky nijak překvapivé (obr. 8). 

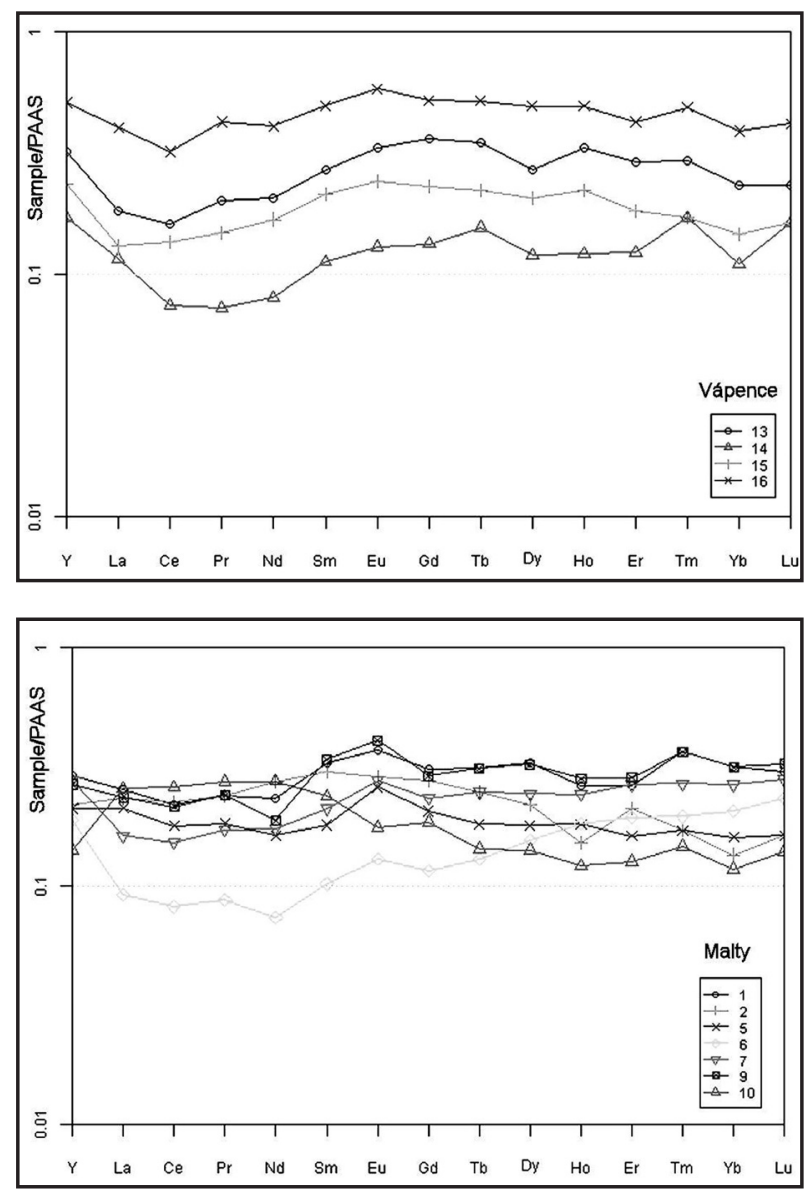

Všechny křivky mají horizontální průběh. V paragenezi těžkého podílu vápenců a zejména studovaných malt (méně v nedopalu) se vyskytují minerály odolné vůči zvětrávání (zirkon, granáty, staurolit, rutil, amfibol, pyroxen, kyanit, sillimanit apod.). Minerální parageneze těžkých minerálů naznačuje, že tyto minerály pocházejí ze smíšených (kyselých i bazických) zdrojů. U malty vz. 6 (M 10; A 9-57, i. č. P 9785/30; hlazená) a nedopalu vz. 8 (F 40, severní předhradí) je patrné určité navýšení HREE.

Ze zvětrávajících granitoidních hornin nebo rul, které mají podobnou koncentraci, pochází např $\mathrm{Zr}, \mathrm{Nb}, \mathrm{Hf}$, Ta, Th, a U. Th a U se během procesu zvětrávání chovají rozdílně. $U$ je, na rozdíl od Th, chemicky mobilní jako $U$, a to odráží vyšší hodnoty Th/U. Podle McLennan et al. (1993) se ve svrchní kůře pohybuje od 3,5 do 4.

Pro zvýraznění rozdílů mezi obsahy stopových prvků byly vypočteny korelace mezi vybranými stopovými prvky (tab. 4). Podle údajů Cullerse $(1994,2000)$ poměr Th/ Cr kolísá ve světlých horninách od 0,13-2,7, v tmavých horninách mezi 0,018-0,046. Hodnoty uvedené v tab. 6 dokládají, že ve studovaných vápencích je poměr Th/Cr mezi 0,01-0,12, v nedopalu 0,01-0,1 a v maltách od 0,04 po 0,34 . Poměr Cr/Th mezi 0,67-19,4 (felsické horniny) a v mafických od 25 do 500 (Cullers 1994, 2000). Z tab. 4 je zřejmé, že poměr Cr/Th ve vyseparovaných nerozložených vápencích je vyšší než 40. Vzorek 11; SVP 2009, hrob 72 a vz. 12; F 040, scht. B 64-35, SVP 2009, i. č. P 242496 dosahují hodnoty 100. Analyzovaný vápenec z Hlohovce má $\mathrm{Cr} / \mathrm{Th}=116,7$. Můžeme předpokládat i př́tomnost detritu z mafických hornin.

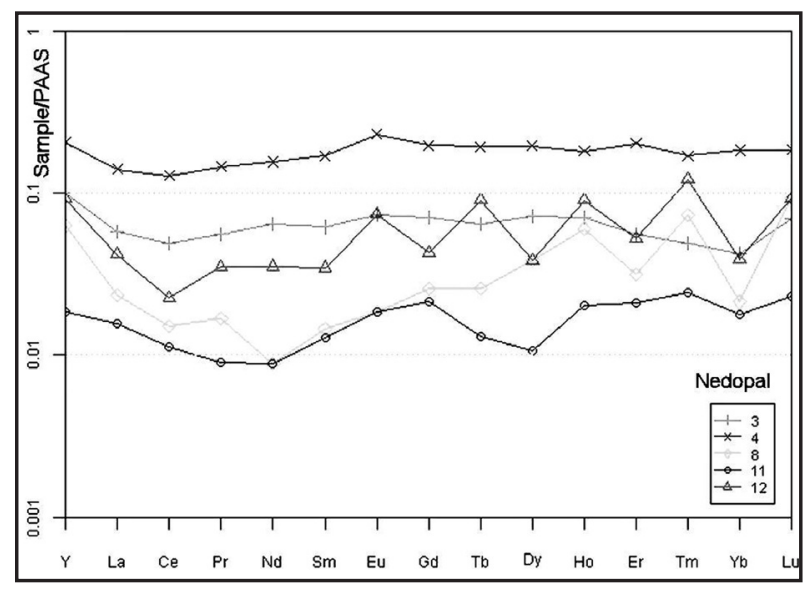

Obr. 8: PAAS normalizovaný REE + Y diagram vápenců, nedopalu a malt $\mathrm{z}$ Břeclavi-Pohanska.

Fig. 8: PAAS normalized REE + Y diagram of limestones, underburned limestones and mortars from Břeclav-Pohansko.

Rozkolísané křivky obsahů některých HREE, zejména v nedopalech vz. 8 (malta F 40, severní předhradí) a vz. 12 (malta F 040, sch. B 64-35, SVP 2009, i. č. P 242496) by mohly dokládat přítomné zuhelnatělé zbytky ve vápencích nebo souvisí s procesem pálení (Masto et al. 2011).

Eu anomálie ve vápencích jsou vysvětlované přitomným detritem (McLennan - Taylor 1991, Taylor - McLennan 1985, Awwiller 1994). Všechny studované vzorky vápenců, vz. nedopalu 3 a $11 \mathrm{Eu} / \mathrm{Eu}^{*}$ jsou shodné s PAAS. Nejvyšší pozitivní anomálii vykazuje nedopal vz. 12 (F 040, sch. B 64-35, SVP 2009, i. č. P 242496) - viz tab. 6.

Middleburg et al. (1988) uvádí, že obsahy Nb a V jsou během procesů zvětrávání méně pohyblivé.

Podle údajů Sprunga (1985) se obsahy vanadu ve vápencích pohybují od 10 do $80 \mathrm{ppm}, \mathrm{v}$ jílových břidlicích 98-170 ppm a v uhlí 30-50 ppm. Ve studovaných vápencích ze Skalice a Holíče je obsah vanadu 8 ppm, vápence z Pálavy mají 37 ppm a z Hlohovce 15 ppm. Vápenné nedopaly vz. 3 (B 64-35, PVR 23), vz. 8 (F 40, severní předhradí) a vz. 12 (F 040, sch. B 64-35, SVP 2009, i. č. P 242496) obsahují 8 ppm V. Dalším prvkem, který se ve vápencích podle Weisweilera et al. (1990) pohybuje v obsazích > 30

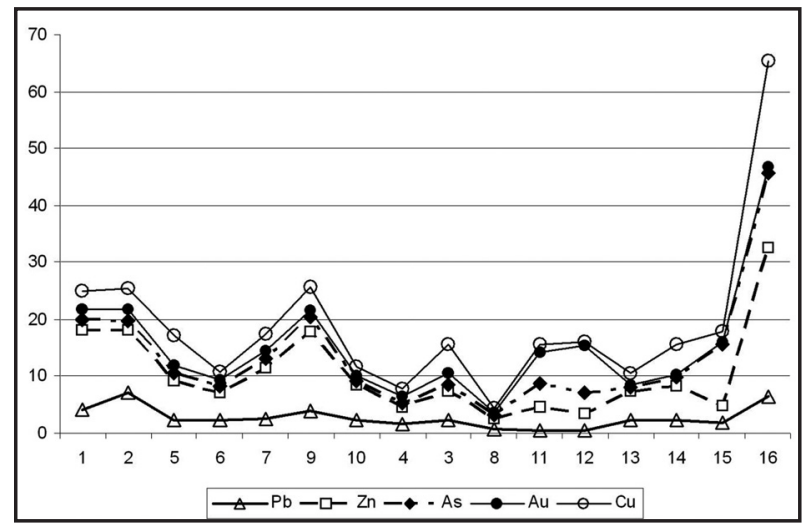

Obr. 9:Zastoupení $\mathrm{Pb}, \mathrm{Zn}, \mathrm{As}$, Au a Cu ve studovaných vápencích, vápenném nedopalu a maltách $\mathrm{z}$ Břeclavi-Pohanska.

Fig. 9: Analysis of $\mathrm{Pb}, \mathrm{Zn}, \mathrm{As}, \mathrm{Au}$ and $\mathrm{Cu}$ in examined limestones, underburned limestones and mortars from Břeclav-Pohansko. 
ppm je Nb. Ve studovaných vápencích, maltách i nedopalu se obsahy $\mathrm{Nb}$ pohybují pod 4 ppm.

Přehled obsahů LREE, HREE a $\Sigma$ REE spolu s ostatními parametry je uveden v tab. 4 . Z tab. 4 je zřejmé, že extrémně nízké jsou obsahy HREE ve vápenném nedopalu. Zcela zanedbatelné jsou REE ve vz. 11 (SVP 2009, hrob 72). Nejvyšší obsahy byly stanoveny ve vápenci $z$ Pálavy. Zastoupení $\mathrm{Pb}, \mathrm{Zn}$, As, Au a Cu je téměř shodné:

- vz. 1 (obj. 34, žárové pohřebiště), vz. 2 (F046, SVP 2009, i. č. $242558 \mathrm{M17}$ ) a vz. 9 (kostel č. 1 sv. od schodů);

- vz. 4 (B 65-33, PVR 01 M 10), vz. 6 (A 9-57, i. č. P 9785/30; hlazená), vz. 10 (kostel č. 1 omítka, prrístavek čs. 605) vz. 13 (vápenec z Holíče);

- vz. 7 (F 40, severní předhradí), vz. 5 (B 64-35, PVR 23; růžová), vz. 3 (B 64-35, PVR 23), vz. 11 (SVP 2009, hrob 72), vz. 12 (F 040, sch. B 64-35, SVP 2009, i. č. P 242496) a vz. 14 a 15 (vápence a $z$ Hlohovce a ze Skalice, viz obr. 9).

\section{Závěr}

Provedené analýzy prokázaly shodu mezi maltami vz. 1 (obj. 34, žárové pohřebiště) a vz. 9 (kostel č. 1 sv. od schodů).

Podobné vlastnosti mají nedopaly malt (vz. 3, 8, 11, 12) a vápenec z Holíče (vz. 13). Malta vz. 6, má chemické složení blízké jak pálavskému vápenci (vz. 16), tak vápenci ze Skalice (vz. 15). Malty (vz. 2, 7, 5), omítka (vz. 10) a nedopal (vz. 4) nemají mezi studovaný vápenci z vytipovaných lokalit odpovídající ekvivalent.

Je velmi pravděpodobné, že pro pálení vápna byly používány vápence z Holíče, Skalice i Pálavy nebo alespoň některý z nich. Tyto vápence jsou si chemicky velmi blízké. Přesto, že v některých parametrech existuje určitá podobnost mezi studovanými maltami a vápencem z Hlohovce, extrémně vysoký obsah $\mathrm{Sr}$ (1 578 ppm) by se musel odrazit jak v maltě, tak i v nedopalu.

\section{Poděkování}

Příspěvek vznikl jako součást řešení výzkumného záměru MSM 0021622427. 


\section{Literatura}

Bílý, M. - Höschel, V. - Kovárník, J. - Puffr, M. (1996): Geofyzikální průzkum románské rotundy sv. Kateřiny ve Znojmě. - Vesmír, 75, 8, 436.

Cullers, R. L. (1994): The controls on the major and trace element variation of shales, siltstones and sandstones of Pennsylvanian - Permian age from uplifted continental blocks in Colorado to platform sediment in Kansas, USA. - Geochimica et Cosmochimica Acta, 58 (22), 4 955-4 972.

Cullers, R. L. (2000): The geochemistry of shales, siltstones and sandstones of Pennsylvanian-Permian age, Colorado, USA: implications for provenance and metamorphic studies. - Lithos, 51, 305-327.

Cullers, R. L. - Podkovyrov, V. N. (2000): Geochemistry of the Mesoproterozoic Lakhanda shales in southeastern Yakutia, Russia: implications for mineralogical and provenance control, and recycling. - Precambrian Research, 104 (1-2), 77-93.

Cullers, R. L. - Basu, A. - Suttner, L. (1988): Geochemical signature of provenance in sand-size material in soils and stream sediments near the Tobacco Root batholith, Montana, USA. - Chemical Geology, 70 (4), 335-348.

Gregerová, M. (2000): Petrografické rozbory malt, jejich relativní datování podle stupně degradace pojiva. - Geologické výzkumy na Moravě a ve Slezsku v r. 1999, 149-151.

Gregerová, M. - Vlček, R. (1994): Petrografická a geochemická charakteristika malt a omítek kostela sv. Petra a Pavla v Brně. Geologické výzkumy na Moravě a ve Slezsku v roce 1993, 104-105.

Gregerová, M. - Pospíšil, P. (2001): Microscopic methods applied to study of historical mortars and plasters. - Proceedings of the $8^{\text {th }}$ Euroseminar on Microscopy applied to Buildings Materials, 353-358. Atény.

Gregerová, M. - Všianský, D. - Procházka, R. - Kurdíková, L. (2010): Petrographic examination of Gothic mortars of the house of Lords of Kunštát in Brno, Czech Republic. - Proceedings of the $2^{\text {nd }}$ Historic Mortars Conference and of the Final Workshop of RILEM TC 203-RHM, 175-186, ITAM Praha.

Gregerová, M. - Hložek, M. (2003): Mikropetrografické rozbory velkomoravských malt a omítek z Mikulčic - 12. kostela. - In: Profantová, N. - Kavánová, B. : Mikulčice - pohřebiště u 6. a 12. kostela, Spisy archeologického ústavu AV ČR Brno, 22, 461-471.

Hošek, J. - Muk, J. (1990): Omítky historických staveb. - SPN Praha.

Hošek, J. - Losos, L. (2007): Historické omítky. - Průzkum, sanace, typologie, Praha.

Kotlík, P. (1999): Stavební materiály historických objektů. - VŠCHT Praha.

Middleburg, J. J. - Van der Weijden, C. H. - Woittiez, J. R. W. (1988): Chemical processes affecting the mobility of major, minor and trace elements during weathering of granitic rocks. - Chemical Geology 68, 253-273.

Prix, D. - Zezula, M. (2000): Archeologický výzkum kostela Nanebevzetí Panny Marie v Branticích, okr. Bruntál. - Archaeologia historica, 25, 279-305.

Přichystal, A. - Doláková, N. - Hladilová, Š. (2008): Kamenné suroviny opevnění na raně středověkém centru Pohansko u Břeclavi (Česká republika) a jejich provenience. - In: Petroarchaeology in the Czech Republic and Poland at the beginning of the $21^{\text {st }}$ Century, 121-131.

Rosen, O. M. - Abbyasov, A. A. - Tripper, J. C. (2004): MINLITH - an experience based algorithm for estimating the likely mineralogical composition of sedimentary rocks from bulk chemical analysis. - Computers and Geosciences, 30, 647-661.

Rovnaníková, P. (2009): Vápno - historie, výroba, vlastnosti. - Konference „Tradiční vápenné technologie“, Národní památkový ústav, Ostrava.

Rovnaníková, P. (2002): Omítky. - STOP, Praha.

Rovnaníková, P. (2003): Historické omítky pohledem technologa. - Konference „Obnova historických omítek“. Společnost pro technologie ochrany památek, Praha.

Rovnaníková, P. (2004): Materiály historických omítek. - Konference „Obnova památek 2004“, AXIS studio, Praha.

Sprung, S. (1985): Technological problems in pyroprocessing cement clinker: Cause and solution. - Cement Industry Publications, 43, 119-128, Düsseldorf.

Šedivý, J. (2010): Geologie a kamenné stavební materiály slovanského centra v Pohansku u Břeclavi. - MS, diplomová práce PřF MU, Brno.

Taylor, S. R. - McLennan, S. M. (1985): The Continental Crust: its Composition and Evolution. - Blackwell.

Taylor, S. R. - McLennan, S. H. (1995): The geochemical evolution of the continental crust. - Review of Geophysics, 33, $241-265$.

Zapletalová, M. (2003): Vliv solí a mikroflóry vlhkého zdiva na sanační omítky. - Stavební obzor, 3/12, 3, 76-79, Praha.

Zeman, A. - Růžičková, E. (1996): Výzkum látkového složení malt. - Technologia artis 4, 93-97. 